\title{
Feed Digestibility and Rumen Fermentation Characteristic in Growing Goat Fed on Diets with Urea-Limestone Mixture Supplementation and Different Nitrogen to Non-Fiber Carbohydrate Ratios
}

\author{
Muhammad Ainsyar Harahap ${ }^{1,2}$, Limbang Kustiawan Nuswantara ${ }^{1}$, Eko Pangestu ${ }^{1}$,
} Fajar Wahyono ${ }^{1}$, Joelal Achmadi ${ }^{1 *}$

\author{
${ }^{1}$ Department of Animal Science, Faculty of Animal and Agricultural Sciences, Diponegoro University, Jl. Prof. \\ Sudharto, Kampus Undip Tembalang Semarang 50275, Indonesia \\ ${ }^{2}$ Present address: Research Unit for Natural Product Technology (BPTBA), National Research and Innovation \\ Agency (BRIN), Gunungkidul, D.I. Yogyakarta, Indonesia \\ *Corresponding author. Email: jachmadi@gmail.com
}

\begin{abstract}
The study examined the effect of limestone-urea mixture (LU) supplementation with different nitrogen (N): non fiber carbohydrate (NFC) ratio in the diet on feed digestibility and rumen fermentation characteristic in growing goat. Twelve Jawarandu local male goats with body weight average of $20.83 \pm 7.42 \mathrm{~kg}$ and aged at $4-6$ months old were randomly distributed into four blocks based on their body weight and received three dietary treatments namely C12, LU12, and LU18. The C12 diet with 1:12 of N:NFC ratio and without LU supplementation, the LU12 diet with 1:12 of N:NFC ratio and LU supplementation, the LU18 diet with 1:18 of N:NFC ratio and LU supplementation. The LU was supplemented at $5 \%$ of total feed. The feed digestibility test was conducted after 12 weeks of feeding trial period and continued by determination of rumen fermentation characteristics. Intake $(\mathrm{g} / \mathrm{d})$ and digestibility of nutrients were unaffected by treatments. The experimental diet did not alter the rumen fermentation characteristics of goats; though, before feeding, the ruminal propionic acid concentration was higher $(\mathrm{P}<0.05)$ in LU supplementation groups than that in control group. The before feeding ratio of non-glucogenic to glucogenic volatile fatty acids were lower $(\mathrm{P}<0.05)$ in LU supplementation groups than that in control group. The supplementation of LU might increase dietary NFC availability in growing goats. The results of this study indicated that adding LU on diet could improve energy utilization by reducing the ratio of non-glucogenic to glucogenic volatile fatty acids.
\end{abstract}

Keywords: Dietary NFC, Limestone-urea mixture, Digestibility, Rumen fermentation.

\section{INTRODUCTION}

Ruminant diet should provide nutrients needed not only for the host animal but also for rumen microorganisms. Energy and protein are sufficiently needed in diet especially at the stage of growing. Ruminant could utilize urea as a non-protein nitrogen source. Normally, urea would rapidly break down into ammonia $\left(\mathrm{NH}_{3}\right)$ and consequently to low nitrogen utilization by rumen microorganisms [1]. In prior study, ruminal nitrogen release of limestone-urea mixture had slower than urea [2]. However, inclusion of limestoneurea mixture in diet is still needed soluble carbohydrate to improve nutrients utilization during rumen fermentation.

Dietary soluble carbohydrate can be measured by its non-fiber carbohydrate (NFC) fraction. Energy supply from NFC fraction composes of monosaccharides, oligosaccharides, starch, fructan and pectin substances [3]. It is hypothesized that a proper N to NFC ratio in the diet may increase rumen microbial growth which in turn improving feed digestibility and rumen fermentation. 
The study was aimed to examine the effect of limestoneurea mixture (LU) supplementation with different nitrogen (N) to NFC ratio in the diet on feed digestibility and rumen fermentation characteristic in growing goat.

\section{MATERIAL AND METHODS}

\subsection{Material}

\subsubsection{Animal and Experimental Diet}

Twelve natives male Jawarandhu crossbred goats about $4-6$ months of age $(\mathrm{BW}=20.83 \pm 7.42 \mathrm{~kg})$ were used in this study. Animals were randomly distributed into four blocks according to their body weight. Individual metabolic cages and access to fresh water were provided to animals. Experimental animals were fed on $\mathrm{C} 12$ diet $(1: 12$ of N:NFC ratio, without supplementation of limestone-urea mixture), LU12 diet (1:12 of $\mathrm{N}: \mathrm{NFC}$ ratio, with limestone-urea mixture supplementation), and LU18 diet (1:18 of N:NFC ratio, with limestone-urea mixture supplementation), respectively. Both LU12 and LU18 diets were supplemented with limestone-urea mixture at $5 \%$ of total feed. The limestone-urea mixture was prepared according to previously reported [2]. Nitrogen and Ca contents of limestone-urea mixture product were $10.66 \%$ and $35.92 \%$, respectively.

\subsection{Methods}

\subsubsection{Sample Collection}

The experiment was conducted for 12 weeks. After 8 weeks of adaptation period to experimental diet and environment, feed digestibility test was conducted in each group. The last week of experimental period was the collection of rumen fluid sample. In the feed digestibility experiment, the feces excretion was collected daily before feeding and then weighted and homogenized. Twenty percent of feces samples were pooled according to dietary treatments over collection period as a representative sample for chemical analyses. Goat rumen fluid sample was taken using vacuum pump-connected stomach tube at before feeding and $3 \mathrm{~h}$ after feeding in the morning. The rumen fluid sample was used for volatile fatty acids (VFA) concentration analyses.

\subsubsection{Chemical Analyses and Statistic}

Chemical content of diet and feces were determined according to the methods of AOAC [4]. Ruminal concentration of volatile fatty acids was measured by using gas chromatography (GC-2010, Shimadzu, Tokyo, Japan) according to Zhang et al. [5].

Data were tested using analyses of variance (ANOVA) according to randomized completely block design. The blocking design was based on different body weight. Significant different between parameters were then performed by Duncan's multiple range test.

\section{RESULTS AND DISCUSSION}

\subsection{Feed Intake and Digestibility}

Dietary treatment did not affect the dry matter (DM), crude protein (CP), and neutral detergent fiber (NDF) intakes (Table 1). This indicated that all diets had similar palatability. In this study, the highest level of dietary NFC was 46\% (LU18 diet), and this diet did not have an effect on nutrient intake. Cannas et al. [3] reported that dietary NFC at a level of $36 \%$ does not affect the DM intake in sheep. Goat would start to lose appetite when level of dietary NFC is $56 \%$ in diet [6]. Excessive dietary non-structural carbohydrate would tend to result subacute ruminal acidosis.

Dietary N to NFC ratio treatment did not affect DM, $\mathrm{OM}$ and $\mathrm{CP}$ digestibility (Table 1). As a result, nutrient digestibility of $\mathrm{C} 12$ diet (control) was similar with those of LU12 and LU18 diets. The similar turnover of feed particle in the rumen might influence nutrient digestibility. Habib et al. [7] stated that passage rate of feed particle out of the rumen contributes to feed digestibility.

Table 1. Feed intake and apparent digestibility

\begin{tabular}{|l|c|c|r|r|c|}
\hline Parameters & C12 & LU12 & LU18 & SEM & $P$ value \\
\hline Daily Intake (g) & & & & & \\
\hline Dry matter & 675.87 & 552.22 & 565.27 & 25.79 & 0.10 \\
\hline Crude protein & 85.96 & 66.63 & 68.45 & 3.63 & 0.07 \\
\hline NDF & 343.84 & 254.96 & 240.60 & 16.73 & 0.06 \\
\hline Digestibility (\%) & & & & \\
\hline Dry matter & 61.59 & 70.06 & 69.37 & 3.06 & 0.63 \\
\hline Organic matter & 63.19 & 72.86 & 71.55 & 2.96 & 0.52 \\
\hline Crude protein & 55.92 & 67.29 & 67.30 & 3.54 & 0.47 \\
\hline NDF & 48.49 & 55.90 & 46.86 & 2.44 & 0.16 \\
\hline
\end{tabular}


Table 2. Rumen fermentation characteristics

\begin{tabular}{|c|l|l|l|c|c|}
\hline Parameters & C12 & LU12 & LU18 & SEM & Pvalue \\
\hline Before feeding & & & & & \\
\hline VFA (mM) & 144.80 & 137.24 & 170.53 & 8.17 & 0.22 \\
\hline C2 $(\mathrm{mM})$ & 83.58 & 76.18 & 92.59 & 5.29 & 0.47 \\
\hline C3 $(\mathrm{mM})$ & $31.59 \mathrm{~b}$ & $38.31^{\mathrm{ab}}$ & $49.47^{\mathrm{a}}$ & 3.05 & 0.04 \\
\hline C4 (mM) & 29.63 & 22.75 & 28.46 & 1.66 & 0.20 \\
\hline $\begin{array}{l}\text { Non-glucogenic to } \\
\text { glucogenic ratio }\end{array}$ & $4.64^{\mathrm{a}}$ & $2.99 \mathrm{~b}$ & $3.06^{\mathrm{b}}$ & 0.25 & $<0.01$ \\
\hline After feeding & & & & & \\
\hline VFA (mM) & 185.06 & 195.94 & 204.19 & 10.92 & 0.78 \\
\hline C2 (mM) & 108.98 & 107.15 & 114.49 & 5.57 & 0.88 \\
\hline C3 (mM) & 45.26 & 57.89 & 60.49 & 5.05 & 0.29 \\
\hline C4 (mM) & 30.82 & 30.89 & 29.21 & 2.23 & 0.95 \\
\hline $\begin{array}{l}\text { Non-glucogenic to } \\
\text { glucogenic ratio }\end{array}$ & 4.67 & 4.71 & 4.76 & 0.02 & 0.33 \\
\hline
\end{tabular}

\subsection{Rumen Fermentation}

The increasing ratio of $\mathrm{N}$ to $\mathrm{NFC}$ in diet improved $(P<0.05)$ before feeding ruminal $\mathrm{C} 3$ concentration (Table $2)$. Ratio of non-glucogenic to glucogenic VFA was lowered $(P<0.05)$ by increasing the $\mathrm{N}$ to NFC ratio at before feeding.

Increasing NFC decreases the acetate proportion and increases propionate which are related to research of Song et al. [8]; Baurhoo and Mustafa [9] and Da-Cheng et al. [6]. Ma et al. [10] reported that the propionate fraction rises with the increasing NFC in the diet. After feeding period, ruminal $\mathrm{C} 3$ concentration and ratio of non-glucogenic to glucogenic VFA were not altered by the dietary treatment. This indicated that observation time needed to be longer than $3 \mathrm{~h}$ after feeding. Although VFA concentrations in C12, LU12 and LU18 diets remained similar, but before and after feeding VFA concentrations of diet with high N to NFC ratio (LU18) were numerically higher than those of $\mathrm{C} 12$ and LU12 diets (Table 2).

\section{CONCLUSION}

Supplementation of limestone-urea mixture in the diet has a high energy for positive relationship between reducing non-glucogenic to glucogenic ratio of volatile fatty acids and energy utilization efficiency in growing goat.

\section{AUTHORS' CONTRIBUTIONS}

Muhammad Ainsyar Harahap: Conceptualization, collection of data, analysis of data, and writing - initial draft. Limbang Kustiawan Nuswantara: conceptualization and manuscript correction. Eko Pangestu: conceptualization and manuscript correction. Fajar Wahyono: conceptualization. Joelal Achmadi: Supervision, conceptualization, manuscript correction and critical review of manuscript.

\section{ACKNOWLEDGMENTS}

This research project was funded by research scheme of Pendidikan Master menuju Doktor untuk Sarjana Unggul Scholarship Batch II 2015, Ministry of Research, Technology and Higher Education, Republic of Indonesia.

\section{REFERENCES}

[1] A. Cherdthong, M. Wanapat, W. Wongwungchun, S. Yeekeng, T. Niltho, Effect of feeding feed blocks containing different levels of urea calcium sulphate mixture on feed intake, digestibility and rumen fermentation in Thai native beef cattle fed on rice straw. Anim. Feed Sci. Technol. 198 (2014) 151157.

DOI:

http://dx.doi.org/10.1016/j.anifeedsci.2014.10.016

[2] M.A. Harahap, L. K. Nuswantara, E. Pangestu, F. Wahyono, J. Achmadi, Nitrogen degradation of the limestone-urea mixtures in the rumen of goats. J. Indonesian Trop. Anim. Agric. 43 (2018) $282-288$. DOI: https://doi.org/10.14710/jitaa.43.3.282-288

[3] A.A. Cannas, C. Cabiddu, G. Bomboi, S. Ligios, B. Floris, G. Molle, Decreasing dietary NFC concentration during mid-lactation of dairy ewes: Does it result in higher milk production?. Small 
Rumin. Res. 111 (2013) 41-49. DOI: https://doi.org/10.1016/j.smallrumres.2012.09.009

[4] AOAC, Official Methods of Analysis Association of Official Agriculture Chemist. Agricultural Chemical; Contaminants; drugs. Vol.1. Association of Official Agriculture Chemists, Inc, Virginia, 1990.

[5] C.M. Zhang, Y.Q. Guo, Z.P. Yuan, Y.M. Wu, J.K. Wang, J.X. Liu, W.Y. Zhu, Effect of octadeca carbon fatty acids on microbial fermentation methanogenesis and microbial flora in vitro. Anim. Feed Sci. Technol. 146 (2008) 259-269. DOI: http://dx.doi.org/10.1016\%2Fj.anifeedsci.2008.01. $\underline{005}$

[6] L. Da-cheng, Z. Xiang-li, Z. Pei-ting, G. Min, H. Hao-qi, H. Hong-lian, Effects of increasing non fiber carbohydrate to neutral detergent fiber ratio on rumen fermentation and microbiota in goats. J. Integr. Agric. 12 (2013) 319 - 326. DOI: http://dx.doi.org/10.1016/S2095-3119(13)60231-2

[7] G. Habib, M. Raza, M. Saleem, Short communication: Effect of tree leaves with or without urea as feed supplement on nutrient digestion and nitrogen balance in sheep. Anim. Feed Sci. Technol. 144 (2008) 335-343. DOI: https://doi.org/10.1016/j.anifeedsci.2007.11.002

[8] S.D. Song, G.J. Chen, C.H. Guo, et al., Effects of exogenous fibrolytic enzyme supplementation to diets with different NFC/NDF ratios on the growth performance, nutrient digestibility and ruminal fermentation in Chinese domesticated black goats. Anim. Feed Sci. Technol. 236 (2018) 170-177. DOI:

https://doi.org/10.1016/j.anifeedsci.2017.12.008

[9] B. Baurhoo, A. Mustafa, Short communication: Effects of molasses supplementation on performance of lactating cows fed high-alfalfa silage diets. J. Dairy Sci. 97 (2014) 1072-1076. DOI: http://dx.doi.org/10.3168/jds.2013-6989

[10] T. Ma, Y. Tu, N.F. Zhang, K.D. Deng, Q.Y. Diao, Effect of ratio non-fibrous carbohydrates to neutral detergent fiber and protein structure on intake, digestibility, rumen fermentation, and nitrogen metabolism in lambs. Asian Australas. J. Anim. Sci. 28 (2015) 1419-1426. DOI: https://dx.doi.org/10.5713\%2Fajas.15.0025 